\title{
OS MÉTODOS DE ALFABETIZAÇÃO NA PRODUÇÃO DO ESPAÇO ESCOLAR
}

\author{
THE SCHOOL SPACE PRODUCED BY THE TEACHING \\ METHODS OF READING AND WRITING
}

Mitsi Pinheiro de Lacerda ${ }^{1}$

Universidade Federal Fluminense

mitsipinheiro@id.uff.br

\section{RESUMO}

O objetivo do artigo é comunicar discussões sobre a reprodução de concepções que estruturam o edifício do método e configuram o espaço alfabetizador. Como procedimento metodológico foram utilizados fragmentos de memórias e de material de pesquisa provenientes de Pesquisa Participante. Mesmo considerando o pressuposto dos métodos sintéticos e analíticos, de que a língua é um produto a ser repassado através de sua fragmentação em parcelas mínimas, os resultados do estudo apontam que os métodos não se restringem a tais procedimentos mecanicistas, pois que suas concepções também produzem relações sociais que configuram o espaço escolar e as consciências. A fragmentação, homogeneização e hierarquização passam a regular o que se passa, sufocando os processos criativos e autorais.

Palavras-chave: Alfabetização; Método; Produção do Espaço.

\section{ABSTRACT}

The article aims to discuss the reproduction of concepts that structure the building of the method and configure the literacy space. As a methodological procedure, fragments of memories and research material from Participant Research were used. Even considering that for synthetic and analytical methods, language is a product to be passed on through its fragmentation in minimal portions, the results of the study point out that the methods are not restricted to such mechanistic procedures, since their conceptions also produce social relations that configure the school space and consciences. Fragmentation, homogenization and hierarchization start to regulate what is happening, stifling the creative and authoritative processes.

Key words: Literacy; Method; Space Production.

1 Doutora em Educação pela Universidade de São Paulo. Professora Associada do Departamento de Ciências Humanas e do Programa de Pós-Graduação em Ensino da Universidade Federal Fluminense. 


\section{Início}

Para os inícios, me servem as metáforas. Pois imagine a língua como uma belíssima sinfonia, e cada nota musical como objeto de um estudo sistemático, repetitivo e rigoroso. Isolada das demais, a nota musical seria ensinada, fixada, avaliada e, tão logo fosse aprendida, seria acrescida a outra nota musical que fora submetida ao mesmo processo e assim sucessivamente, até que, um dia, o aprendiz pudesse assoviar a melodia que já Ihe era anteriormente familiar aos ouvidos. Esta improvável metodologia em muito se assemelha ao que ocorre, ainda hoje, no âmbito da alfabetização. Os métodos sintéticos tomam como ponto de partida a exposição e estudo de unidades mínimas da escrita (letras, sons das letras e sílabas) e sua aglutinação progressiva até a culminância de textos forjados com as unidades repassadas.

Os métodos sintéticos têm em comum o pressuposto de que a língua é um produto a ser repassado ao aprendiz (BAKHTIN, 1992), e que o sucesso deste repasse pode ser garantido pela fragmentação do produto em parcelas mínimas a serem reconstituídas em seu conjunto, por quem as recebe. Na contramão desta trajetória progressiva, os métodos analíticos também tomam a língua como um produto, mas partem do estudo de historietas desprovidas de significado através de sua memorização, repetição e novas composições, tudo isso com o emprego restrito das unidades que foram repassadas.

Em geral, estes métodos tomam como suporte a visão, a audição e até mesmo outros aspectos sensoriais como o tato, ao estimularem a manipulação de letras móveis. A alfabetização seria entendida enquanto transposição destes aspectos sensoriais em caracteres gráficos, e a escrita seria a representação codificada da fala. Disto resulta uma forte aderência à ideia de que a unidade empregada no ensino da leitura e escrita (letra, sílaba, palavra ou texto) deva ser trabalhada no interior da transposição entre fala e escrita. Diferentes em seus procedimentos, os métodos são diretamente relacionados ao ensino.

Na década de 1980, Ferreiro \& Teberosky (1984) deram início à ruptura com estas versões direcionadas ao ensino, ao tratarem da alfabetização a partir do ponto de vista de quem aprende. Enquanto isso, no Brasil, uma literatura crítica que surgia desde a práxis, denunciava o mecanicismo posto pelos métodos de alfabetização. Dentre as referências brasileiras deste período encontram-se, por exemplo, os estudos que tomam a alfabetização como processo discursivo em contextos de interação, abordando as relações entre pensamento e linguagem (SMOLKA, 1993); as proposições por uma prática alfabetizadora através de textos (GERALDI, 1984); a importantíssima luta política pela educação das classes populares (GARCIA, 1992) e tantos outros estudos comprometidos com o legado de nosso mestre maior, Paulo Freire, para quem a alfabetização é uma prática que liberta a palavra e a consciência.

Embora os estudos em educação no Brasil já contem, há mais de quarenta anos, com relevante produção crítica e provocativa à criação de novos conhecimentos em alfabetização, ainda é comum encontrarmos nas escolas professoras que preservam concepções inerentes aos métodos - ao mesmo tempo em que inauguram novidades. Na complexidade das práticas, professoras alfabetizadoras aplicam determinados métodos e fazem uso de técnicas mecanicistas, enquanto reivindicam sua própria criatividade e se envolvem com a inventividade de práticas sociointeracionistas. A aderência a uma orientação específica não guarda a mínima fidelidade, pois professoras tanto produzem suas práticas, quanto reproduzem ideias alheias com bastante frequência. Devido a isso, a classificação docente segundo sua orientação teórico/metodológica é algo que implodiria qualquer estatística ou taxonomia, pois "mesmo com a hegemonia do pensamento construtivista no Brasil, continuaram a ser utilizadas cartilhas, que, novas ou antigas, sempre contêm concretização de métodos (sintéticos, ou analíticos, ou mistos) de alfabetização, os quais, portanto, nunca deixaram de ser utilizados por alfabetizadores" (MORTATTI, 2009). 
Nem sempre é possível avançar na discussão acerca da classificação da prática docente, pois as escolhas que as orientam têm raízes na formação docente, no processo de escolarização da professora, em sua história de vida, no nível de regulação institucional a que é submetida no trabalho, em currículos prescritos, em suas crenças e em vários outros âmbitos políticos, acadêmicos, privados e até místicos. Conforme aprendemos com Alves (2017), a formação é tecida em "redes de práticasteorias [...]. Essa ideia tem permitido uma compreensão mais complexa da formação e dos currículos uma vez que nos leva a entender o estabelecimento de processos" (p. 3 - grifo da autora).

Penso ser importante esta breve alusão ao perfil docente, para que eu possa avançar na apresentação do objetivo deste estudo. Embora a figura da professora tradicional não exista em sua "forma pura", os métodos e toda sua engenhosidade mecanicista não dispensam a circunscrição de seus domínios. A professora transita de um método a outro, mas o método, ao ser utilizado, não se dobra. Contrabandeado, ele permanece fiel às suas origens.

É possível que uma professora que faça uso de determinado método de alfabetização apresente pouca disposição para discutir, praticar ou aderir a outra proposição. Isto ocorre porque sua prática obteve resultados anteriores que the atestaram a veracidade do método - o que intensifica o pragmatismo, já que "a unidade imediata de pensamento e ação implica na inexistência de diferença entre correto e verdadeiro na cotidianidade" (HELLER, 1992, p. 32). Embora a prática se manifeste externamente ao sujeito, ela produz transformações internas pouco visíveis e exploradas - dadas as raras oportunidades de conversação e reflexão coletiva sobre a prática.

Em se tratando de alfabetização, um método não seria tão somente um conjunto de procedimentos a serem empregados, cujo objetivo conduziria uma prática até o êxito: o método também produz relações sociais que configuram o espaço e as consciências. A reprodução de passos pré-estabelecidos de um método e a inventividade da prática pela professora não somente resultam em determinados tipos de atividades, intervenções e proposições didáticas oferecidas à criança. Recorrendo às discussões de Lefebvre (2000) acerca da produção do espaço, entendemos que diferentes usos de diferentes concepções acerca da alfabetização também produzem relações sociais de naturezas diversas: produzem o espaço alfabetizador e as consciências.

Os métodos sintéticos e analíticos não somente se prestam ao estabelecimento de práticas mecanicistas e sem sentido: eles também configuram o espaço. Este é, portanto, o objetivo do artigo: pensar sobre a reprodução, no cotidiano escolar, de concepções que estruturam o edifício do método e configuram o espaço alfabetizador. Estas breves considerações iniciais se prestam a esclarecer que, durante a escrita deste artigo, meu interesse não se repousou sobre a relevância dos métodos e a incidência de seu consumo, mas sobre a busca dos lastros residuais de sua ocorrência.

Anunciado o objetivo, é hora de apresentar a metodologia. Para isso, recorro à literatura. $\mathrm{Na}$ década de 1860, Dostoiévski realizou sua primeira viagem ao ocidente. Durante aproximadamente oitenta dias esteve na Alemanha, França, Suíça, Inglaterra e Itália. Passados alguns meses, já tendo retornado à Rússia, acedeu aos pedidos de amigos para que descrevesse suas impressões sobre a viagem. A resposta veio através de crônicas escritas com o auxílio de seu caderno de notas, o que nos leva a crer, conforme ele anuncia a princípio, de que se tratariam de descrições - ou seja, que ele registraria, por escrito, o retrato do que viu. Contudo, em lugar de uma narrativa a serviço do detalhamento do lugar, encontramos reflexões críticas acerca da submissão russa a um modo de vida e cultura estrangeiras. 
Distante temporal e fisicamente dos lugares visitados, Dostoiévski avisa aos leitores, algumas vezes, que irá mentir. Para ele, não é possível a um observador reter e examinar tudo o que viu e nem representar uma realidade sem que o vivido por ele afete esta representação. Em sua viagem, aparentemente ele não se deteve na observação de monumentos históricos e lugares turísticos, pois que estava ocupado a olhar com estranhamento para um modo de vida que não era próprio de sua Rússia agrária, mas que nela já se instalava; um modo de vida que dava sinais de ser governado pelo capitalismo. Ele pergunta:

Meu Deus, que espécie de russos nós somos? [...] Somos realmente russos? Por que a Europa exerce sobre nós, sejamos quem formos, uma impressão tão forte e maraviIhosa, e tamanha atração? [...] Porque tudo, decididamente quase tudo o que em nós existe de desenvolvido, ciência, arte, cidadania, humanismo, tudo, tudo vem de lá, daquele país das santas maravilhas! Toda a nossa vida se dispôs em moldes europeus, já desde a primeira infância. Será possível que algum de nós tenha podido resistir a esta influência, a este apelo, a esta pressão? Como foi que ainda não nos transformamos definitivamente em europeus? (DOSTOIÉVSKI, 2011, p. 79)

Da viagem, ele não reteve o retrato físico do lugar, pois que estava ocupado com a possessão de uma cultura estrangeira sobre a sua. Daí que suas "Notas de inverno sobre impressões de verão" (2011) não oferecem, ao leitor, um relato de viagem, mas o espanto do viajante ao encontrar o berço de uma dinâmica social tecnicista, burocrática e controladora, cujos traços se instalavam no país em que vivia. Seu espanto alimenta o meu, provocando-me uma paródia:

Meu Deus, que espécie de professoras nós somos? [...] Somos realmente professoras? Por que o Método exerce sobre nós, sejamos quem formos, uma impressão tão forte e maravilhosa, e tamanha atração? [...] Porque tudo, decididamente quase tudo o que em nós existe de desenvolvido, ciência, arte, cidadania, humanismo, tudo, tudo vem de lá, daquele Método das santas maravilhas! Toda a nossa prática pedagógica se dispôs em moldes, já desde a primeira turma de alfabetização. Será possível que alguma de nós tenha podido resistir a esta influência, a este apelo, a esta pressão? Como foi que ainda não nos transformamos definitivamente em máquinas de ensinar? (Paródia com DOSTOIÉVSKI, 2011, p. 79)

As "Notas" de Dostoiévski instigam a pensar nas diversas camadas que se interpõem às nossas observações. Olhar para o que se passa é diferente de olhar para o que nos acontece enquanto algo se passa. Desde suas preciosas reflexões, é que me aproximo dos métodos direcionados à alfabetização. Fartamente descritos em seus procedimentos e criticados em suas proposições reducionistas, neste artigo os métodos são observados segundo aquilo que produzem nos sujeitos, nas relações e na produção do espaço escolar.

Considerando a realidade na qual este texto é escrito, quando a proximidade física com a escola se encontra interrompida pela crise sanitária de COVID-19, busco em anotações, memórias e experiências vividas o material de pesquisa necessário à redação. Apresento, portanto, minhas "notas de distanciamento social sobre impressões de práticas pedagógicas anteriormente visitadas". Inspiro-me no título de Dostoiévski (2011), "Notas de inverno sobre impressões de verão", para justificar o emprego, neste artigo, de fragmentos de memórias e de material de pesquisa que não são contemporâneos a esta escrita.

Assim, durante a escrita, inseri reminiscências provenientes de épocas remotas relacionadas a práticas alfabetizadoras. Todo o material de pesquisa foi encontrado em anotações de campo registradas durante uma Pesquisa Participante ocorrida em 2018, e em experiências vividas o que impregnou este material com uma saborosa nebulosidade que me dispus a desvendar. 
Mas não apenas isso. Note que, ao escrever sobre o que se passou há algum tempo, Dostoievski avisa que irá mentir. Eu aviso que mentirei, também. E antes que os rigores me acendam uma fogueira, explico. Se a confissão da mentira for tomada literalmente, o leitor deverá encerrar aqui a sua leitura e eu me encontrarei em maus lençóis. Então, explico: penso que há nisso uma crítica ao ainda imperativo modo positivista segundo o qual a pesquisa em ciências humanas precisa descrever, quantificar e classificar a realidade. A mentira nos liberta da impossível tarefa de retratar a realidade. Ela permite que o conhecimento que produzimos seja acompanhado por aquilo que nos tornamos, ao produzir este conhecimento - algo que aprendemos com Santos (2002).

\section{A constituição do método: heranças da modernidade urbana e industrial}

Embora os métodos de alfabetização difiram entre si, todos são produzidos segundo concepções similares. Dentre estas, distinguimos a fragmentação, classificação, ordenação, hierarquização e homogeneização. É possível encontra-las em qualquer método de alfabetização tradicional. Veja o método fônico: ele toma a enunciação, a retira de contexto, isola um fonema, cria para ele pré-requisitos em uma lógica seriada, estabelece procedimentos para que este fonema seja transmitido e atua no sentido de universalizar estas etapas. Veja o método silábico: ele toma a enunciação, a retira de contexto, isola uma sílaba, cria para ela pré-requisitos em uma lógica seriada, estabelece procedimentos para que esta sílaba seja transmitida e atua no sentido de universalizar estas etapas.

Pois bem. Estas concepções não são de uso exclusivo da constituição dos métodos. Para Lefebvre (2000), elas são fortalecidas a partir da modernidade inscrita pela nova sociedade urbana industrial. O que adentra a prática alfabetizadora, portanto, não é somente o método, mas as concepções que o forjaram. Uma vez revitalizadas, estas ideias passam a configurar todo o espaço, inclusive as relações sociais. Com isso, processos são convertidos em etapas homogêneas, aprendizagens são dissecadas em níveis de conceitualização e a palavra é conduzida à força até os dispositivos de fragmentação.

Para Henri Lefebvre (2000), o conhecimento acerca das relações sociais nas sociedades capitalistas urbanas demanda a emergência da discussão acerca da produção do espaço. Com os processos de industrialização e urbanização, um espaço anteriormente inexistente foi constituído - espaço estranho à natureza, porque subordinado ao imperativo dos modos de produção capitalista. Vejamos: as relações sociais provenientes dos modos de produção inauguram, no meio urbano, um espaço que reproduz, em si, estas relações sociais de produção. As ideias de fragmentação, hierarquização e homogeneização presentes no processo produtivo se inscrevem no tecido urbano, afetando as relações sociais que passam a ser orientadas pelos mesmos princípios. Bem guardada no armário da professora alfabetizadora, em sua sala de aula, a cartilha não dispõe de imunidade alguma contra isso.

Os mesmos princípios que regulam as relações sociais de produção, também determinam a estrutura, sequenciamento e direção do método oferecido pela cartilha. Fragmentar o processo produtivo na fábrica, oferecer um fonema por vez, na escola. Determinar o lugar ocupado por cada operário na linha de produção, afixar as letras do alfabeto isoladamente, em cima do quadro de escrever. Especificar o tempo destinado à produção de cada peça, dividir o tempo destinado à aprendizagem de cada sílaba. Vigiar para que o trabalho obedeça ao ritmo, primar para que as mesmas atividades escolares sejam cumpridas ao mesmo tempo. Premiar um funcionário para que seu corpo sirva de exemplo aos demais, hierarquizar as aprendizagens das crianças com inocentes estrelas douradas. 
O espaço social recebeu, como herança, as ideias de fragmentação, hierarquização e homogeneização advindas da modernidade urbana e industrial (LEFEBVRE, 2000). Nos métodos tradicionais de alfabetização, a palavra é fragmentada e a cada parcela é atribuída uma distinção específica que a posiciona em uma trajetória que deve ser percorrida por todos, segundo ritmo e direção semelhantes. Há muito o que se observar neste processo, ao considerarmos o que é produzido ali.

As concepções do método não somente limitam a polissemia e a autoria da palavra: elas também produzem o espaço social. A fragmentação da palavra conduz necessariamente a uma hierarquia de suas parcelas: primeiramente são ensinadas as vogais, depois as consoantes; fonemas são escalonados segundo uma suposta gradação de complexidade. Toda esta arquitetura fragmentada e hierárquica alimenta a competitividade e inibe a autoria, posto que parte do princípio de que aprende melhor quem reproduz, sem alterações, o que lhe foi repassado. A educação bancária (FREIRE, 1987) engendra ambiências propícias à competição entre quem aprende, através da exposição dos resultados que obtiverem as melhores considerações.

O método de alfabetização supera sua forma gráfica presente na cartilha: ele também se infiltra na corporeidade, nas expectativas, nas relações, nas consciências. Na sala de aula, a criança se torna estrangeira. Ao adentrar a classe, ela encontra fixadas nas paredes letras isoladas, efemérides, regulações e textos que não são de sua autoria. A criança não se identifica com estes artefatos didáticos, pois que não esteve presente no momento de sua criação e exposição. Na tarefa de casa, recebe um exercício cuja formulação não contou com sua participação. No livro didático e no caderno, a repetição da língua materna Ihe afigura como coisa morta, porque desprovida de sua enunciação (BAKHTIN, 1992). A presença do texto quase sempre se reduz à reprodução de fórmulas canônicas que transmitem o fonema, ou a sílaba tomada como objeto de estudo. Os textos escritos pela criança, em grande parte, servem para que a professora avalie sua aprendizagem e depois são encaminhados ao cemitério dos textos escolares. A criança escreve e sua escrita não é lida, exposta nas paredes, admirada, discutida.

No livro didático e nas infinitas proposições que podem ser acessadas na Internet, o texto é reduzido a uma função. Isolado de um contexto e fragmentado, o texto é submetido às análises fonética, morfológica e sintática. Ele perde o sentido e é convertido em produto a ser consumido. O mesmo produto para todos, o mesmo modo de consumo. A fragmentação produz minúsculos objetos de estudo que são organizados segundo níveis de complexidade arbitrários. A classificação destes pequeninos objetos desprovidos de sentido estabelece uma hierarquização segundo a qual primeiramente deve-se ensinar o mais simples, até que se possa alcançar o que é considerado mais difícil. Toda esta mecânica torna homogênea a prática pedagógica, o material didático empregado e o currículo. Ao tomar o método enquanto referência à prática alfabetizadora, as concepções que o constituem se imiscuem nas relações sociais e na produção do espaço escolar. A fragmentação, homogeneização e hierarquização passam a regular o que se passa, sufocando os processos criativos e autorais.

Tomemos um exemplo facilmente encontrado em um buscador da Internet. Ao digitar os termos "atividade de alfabetização" são apresentadas uma infinidade de proposições que podem ser impressas. Trata-se da conhecida "folhinha". Tomemos a primeira delas - o que, neste caso, pode ser considerado representativo das demais atividades disponíveis. O enunciado solicita que o aprendiz complete palavras com sílabas. As sílabas são apresentadas isoladamente e devem ser copiadas em lacunas para que formem palavras. A atividade é ilustrada com imagens referentes às palavras que devem ser completadas. 
Figura 1 - Atividade coletada através de buscador na Internet

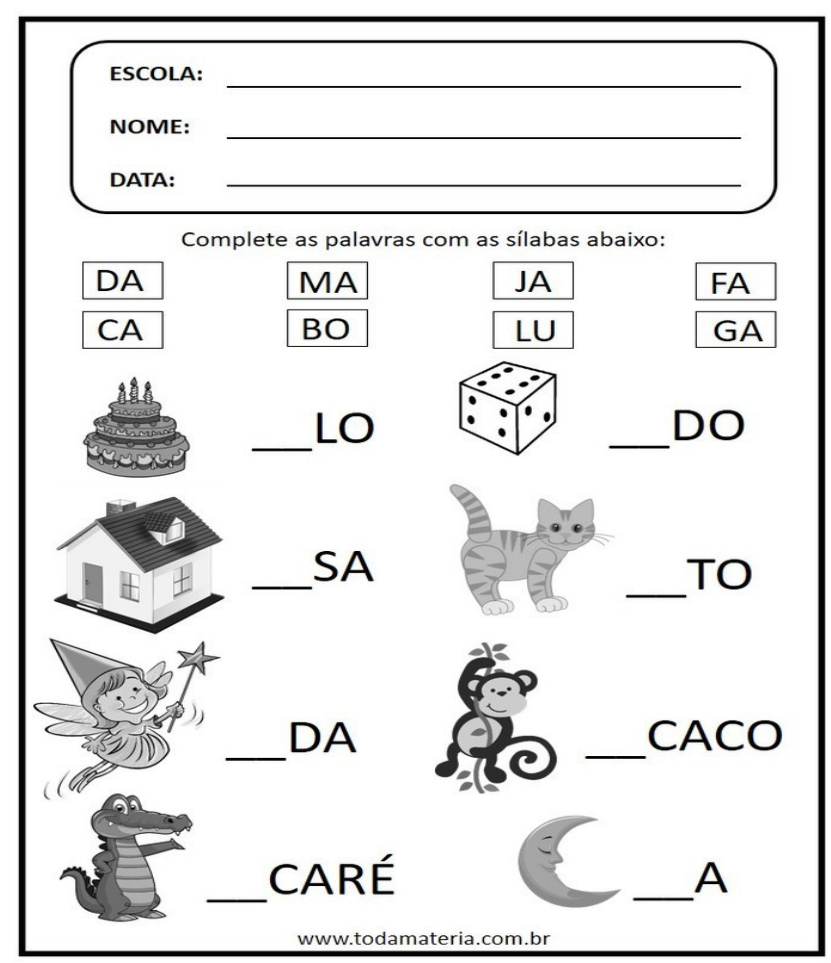

Fonte: Google, 2021

A criança recebe a folhinha e se põe a decifrar a proposta. A professora explica, a criança escuta, olha para a folhinha do colega, olha para a folhinha dela, olha para a janela, parece que tem gente no pátio, hoje tem sol, vai dar para brincar no recreio. O colega debruçado sobre a folhinha, melhor ver o que ele fez, ah, sim, tem uns risquinhos, ele escreveu nos risquinhos. DA - MA - JA - FA, tudo escrito dentro de uns quadradinhos, deve ser isso, copiar isso.

Ah, mas você está mentindo, não é possível que isso tenha acontecido. Bom, eu entrei aqui de braços com o Dostoiévski e avisei que iria mentir. Em minhas mentiras, vi que outra criança olhou para a folhinha e rapidamente escreveu as sílabas bem em cima das linhas sem sequer espiar as sugestões. E outra criança passou o tempo colorindo os desenhos, e outra copiou qualquer sílaba em qualquer lugar, e outra copiou do colega, e outra pediu ajuda à professora, e outra escreveu VELA no BOLO e MENINA na FADA - e assim foi.

A atividade era: complete as palavras. Para que pudessem ser completadas, as palavras tiveram que ser, primeiramente, fragmentadas. Um pedaço Ihes foi retirado, isolado dentro de um quadrado e organizado segundo uma lógica qualquer. Este gesto que divide adentra a consciência tanto da professora quanto da criança, forjando a ideia de que para conhecer, é preciso reduzir o que se conhece em partículas mínimas. A mesma tarefa foi destinada a todos: desde à criança que a realizou sem titubear, até à criança que não se conectou à proposta de completar o que nunca deveria ter sido dividido. A homogeneização da atividade também adentra as relações, fazendo crer que todos devem seguir o mesmo percurso, no mesmo tempo, em direção ao mesmo lugar. Mas as diferenças se interpõem a este projeto de racionalidade, e a resposta que recebem é o estabelecimento de hierarquias segundo as quais uns sabem mais, outros sabem menos, e outros nada sabem. A hierarquização proveniente dos diferentes níveis de proficiência complementa este quadro, tornando imperativo, na produção do espaço escolar, as escalas de excelência em cujo mais baixo degrau se produz a exclusão. 
As atividades estão presentes no livro didático e nos buscadores da Internet, disponíveis ao infinito. Basta acessar, copiar, colar e imprimir. A tarefa produtiva da escola demanda que desta pequena indústria surjam, diariamente, tarefas a serem realizadas. A folhinha é a comprovação deste trabalho: algo foi feito. Mas, como a reprodução da atividade e sua aplicação na prática pedagógica afeta a produção do espaço?

\section{0 que the acontece quando você cria ou reproduz?}

Vimos que o método de alfabetização dispõe de procedimentos que orientam a prática pedagógica e fomentam a produção em série de atividades. Vimos também que as concepções presentes no método são transferidas às atividades, às relações e atuam na produção do espaço escolar. Estas concepções, fortemente presentes na modernidade, visam ordenar a realidade de forma a que ela se apresente uniforme e passível de ser controlada. Muito falamos sobre isso, e muitas críticas são dirigidas aos métodos de alfabetização (SAMPAIO et al., 2019) por ignorarem o sentido, por negarem as enunciações, por estabelecerem uma mecânica, por incentivarem a reprodução. Mas, o que nos acontece quando criamos, ou quando reproduzimos algo?

Se até aqui Dostoievski me acudiu com suas mentiras, penso que seria de grande serventia pedir-Ihe ajuda novamente. Vamos, pois, ao encontro do personagem Ivan Matviéitch (DOSTOIÉVSKI, 2011), funcionário público que, certo dia, convida a esposa a ver um crocodilo que se encontrava exposto à visitação. As pessoas acorriam ao lugar para observar o tal espetáculo - um crocodilo enorme, dentro de uma tina, aparentemente imóvel. Após observar o animal, a curiosidade da esposa rapidamente se dissipou e ela tratou de se dirigir aos macacos. Foi quando se ouviu um grito no salão. O crocodilo havia engolido Ivan Matviéitch.

Não morreu. Após idas e vindas descobriu-se que o interior do crocodilo era inteiramente oco, e que Ivan Matviéitch não teve dificuldades para se adaptar à nova morada. Tomou jeito no espaço abdominal do bicho de forma a garantir condições a seu trabalho como servidor público, e ali deu continuidade à sua existência. Segundo os especialistas, Dostoiévski escreveu este conto com o intuito de criticar a subalternização da Rússia aos costumes europeus, mas eu gosto também de pensar nesse Ivan Matviéitch que foi engolido contra a sua vontade e sem a sua iniciativa, mas, que uma vez engolido, se adaptou àquilo que o cerceava.

O interior do crocodilo constituía um espaço fisicamente diferente do escritório no qual trabalhava Ivan. A diferença física de ambos os espaços, contudo, não foi obstáculo à sua adaptação ao novo local de trabalho. Retido no imenso abdômen do bicho, Ivan encontrava as mesmas condições à continuidade de sua rotina: as tarefas previamente classificadas segundo o grau de urgência de cada uma, o tempo destinado a cada atividade e a missão por repetir, continuamente, os mesmos gestos habituais. A distinção física entre o velho e o novo local de trabalho não foi questionada por Ivan, uma vez que se encontravam, garantidas, as mesmas condições de trabalho.

Com isso aprendemos, a partir de Lefebvre (2000), a pensar sobre o espaço enquanto produto de relações sociais - e não somente como o espaço geométrico que nos é tão familiar. Não são as paredes de alvenaria do escritório ou as paredes abdominais do crocodilo que constituem o espaço para Ivan, e sim a perpetuação de concepções que forjam, para ele, sua ambiência laboral. Cotidianamente, Ivan copia. Seus gestos foram reduzidos a uma mecânica que dispensa qualquer reflexão. Isso constitui o espaço por ele habitado - não o espaço físico - mas o espaço no qual encontra condições para reproduzir as mesmas dinâmicas que the são familiares. 
Em se tratando de alfabetização, a reprodução do método culmina no consumo de produtos que foram definidos, previamente, por este método. A professora e as crianças cumprem tarefas nas quais não se reconhecem, já que estas tarefas não são provenientes de suas conversações e nem se conectam às suas historicidades. Ao propor a execução de uma tarefa do livro didático ou oferecer uma atividade reproduzida desde as infindáveis que se encontram disponíveis, a professora oferece à criança um produto. Além de não ter sido criada na interação dialógica entre ela e as crianças, a atividade também opera o silenciamento da linguagem, ao abordar, tão somente, a estrutura da língua (BAKHTIN, 1992). O que acontece, então?

O que acontece quando processos de ensinar e aprender são direcionados à execução de tarefas que não foram criadas por quem as irá desenvolver? Que tipo de relações estas tarefas - meros produtos alheios à dinâmica pedagógica - estabelecem junto à produção do espaço? O que se passa com a professora quando sua prática é orientada pela disseminação de produtos alheios à sua criação intelectual? O que acontece com as crianças quando recebem proposições que não as inscrevem enquanto autoras?

Tomar uma atividade que se encontra disponível e aplica-la ao processo alfabetizador pode ter suas serventias quando nos deixamos conduzir. As atividades são facilmente acessadas e reproduzidas, e isso oferece resposta imediata às exigências das famílias e do sistema escolar pela produtividade. O ritmo do trabalho torna-se homogêneo e controlável, dada a execução do mesmo por todas as crianças. A avaliação ganha força em sua centralidade excludente, já que baseada em propostas idênticas oferecidas a todos. A adequação à prescrição curricular faz-se de modo satisfatório, com a agilização das correspondências entre a atividade proposta e o código alfa numérico disposto na Base Nacional Comum Curricular. É... tanto os livros didáticos, quanto as atividades disponíveis on line, trazem consigo o código específico. Enquanto tudo isso se passa, o espaço escolar absorve as marcas da fragmentação, homogeneização e hierarquização, afetando expectativas e delineando as relações sociais. Um pequeno pesadelo cotidiano.

Enfim, é importante que se observe as concepções que orientam as práticas - práticas que se repetem como "produtos", ou práticas que surpreendem porque se constituem enquanto "obras". Quanto ao produto, pouco há que se dizer: trata-se de algo reproduzido desde a consecução de procedimentos operacionais específicos, que mimetiza o modelo de uma esfera central e é disponibilizado ao consumo universal. O produto "pedagógico" encontra-se fartamente disponível, sua aparência falsifica o lúdico e atende ao economicismo próprio da vida cotidiana (HELLER, 1992). Quanto à "obra",

Mentalmente, o termo "obra" não designa mais um objeto de arte, mas uma atividade que se conhece, que se concebe, que reproduz suas próprias condições, que se apropria dessas condições e de sua natureza (corpo, desejo, tempo, espaço), que se torna a sua obra. Socialmente, o termo designa a atividade de um grupo que toma em suas mãos e a seu cargo seu papel e seu destino social, ou seja, uma autogestão (LEFEBVRE, 1991, p. 215 - grifos e aspas do autor).

Práticas convertidas em produtos ocorrem desde a aplicação rigorosa de métodos prescritos e da aplicação de atividades supostamente neutras. Diferente disso, o trabalho que toma a prática enquanto teorização, conduz à criação da obra de arte: uma prática pensada a partir das concepções com as quais se pretende produzir o espaço. Vejamos um exemplo de atividade que consideramos uma "obra", tomado de uma atividade desenvolvida com uma turma ${ }^{2}$ do primeiro ano de escolaridade.

2 Esta atividade foi desenvolvida coletivamente pela pesquisadora, estudantes do curso de Pedagogia, a professora da escola e suas 
Influenciada por orientações postas pela Pesquisa Participante, organizamos um grupo para criarmos uma atividade em alfabetização. Este grupo era constituído pela pesquisadora, por algumas alunas do curso de Pedagogia e por uma professora alfabetizadora. Durante a criação do jogo buscamos não reproduzir nenhuma proposta que fosse por nós conhecida, mas de criar algo a partir de concepções que considerássemos relevantes. Sendo assim, antes criarmos o jogo, primeiramente estabelecemos quais seriam estas concepções. Após a conversação, decidimos que o jogo deveria incluir as ideias de colaboração, interação, ludicidade, liberdade e autoria. Criamos, então, o jogo "O gato sumiu!" e convidamos as crianças desta turma para brincar e aprender.

O jogo consistia na apresentação do desenho de uma criança, o qual retratava uma paisagem constituída por árvores, vegetação, um rio e um banco. Havia também nuvens e sol no céu. Informamos à turma que o desenho era de uma criança e contamos uma história divertida que era inventada e intensificada segundo as emoções entre a contadora da história e seus ouvintes. Era algo relacionado a um gato fugido. O gato fugira de casa e seu paradeiro era desconhecido, mas alguém havia visto o bichano: a criança autora do desenho. O gato estaria ali, no desenho.

O desenho correu de mão em mão, provocou conversações, discussões, risadas. Então, propomos às crianças uma tarefa: metade da turma escreveria a suposta localização do gato, e a outra metade deveria ler os escritos e desvendar o mistério. A sala ferveu. As crianças escribas se reuniram para decidir onde estaria o gato - se na árvore, se no banco, se na vegetação, se tomando um banho de rio. "Gato não gosta de água, no rio não". "Na árvore sim, já vi gato na árvore". "Ah, mas se estivesse na árvore todo mundo via". "Deve estar no mato". "Escondido debaixo do banco? Lá em casa o gato entra debaixo dos móveis" - diziam as crianças.

Discutiam e escreviam. Junto a isso, cuidavam da legibilidade da escrita, pois esta seria lida pelas crianças incumbidas da resolução do caso. Finda a tarefa, as "pistas" para a localização do gato foram entregues às crianças que as aguardavam. Começou ali outro movimento: ler o que estava escrito, discutir as indicações diversas, falar, ouvir, interagir.

Figura 2 - Desenho e escritas de crianças no jogo "O gato sumiu!"

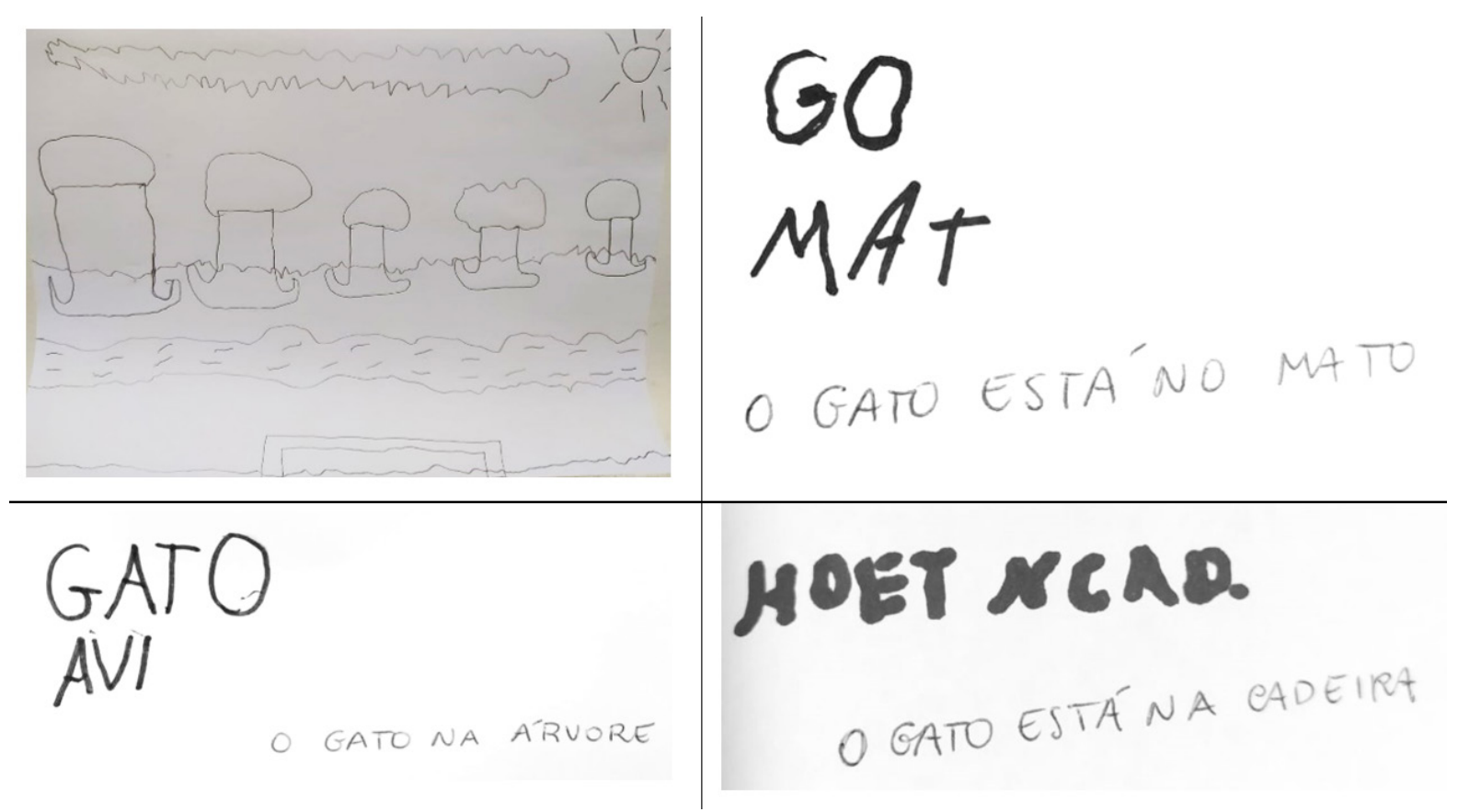

Fonte: Material de pesquisa, 2018

crianças do primeiro ano de escolaridade. A atividade ocorreu em uma escola pública, no município de Santo Antônio de Pádua/RJ, em 2018. 
Não me lembro onde, por fim, decidiram que estaria o gato. Isso não interessa. O importante, aqui, foi o processo: uma atividade foi criada a partir de concepções cuidadosamente escolhidas. Estas concepções orientaram a invenção do jogo e afetaram as relações que ocorreram, as conversações, a produção da escrita e a leitura. Toda a ambiência ficou impregnada de colaboração, interação, ludicidade, liberdade e autoria. Não era um jogo para jogar "contra" o outro: era preciso estabelecer uma lógica para a escrita, e esta escrita deveria ser bem pensada, bem registrada, para garantir sua legibilidade. Não havia espaço para a competição, assim como não era possível jogar sozinho: as crianças interagiram entre si o tempo todo. Fizeram emergir de si a ludicidade necessária para fantasiar as tropelias do gato fugido, em práticas de liberdade, anunciando ao outro suas autorias.

\section{E cadê o gato?}

Não sei, e já disse que isso não importa. Pare de procura-lo, olhe para o espaço. Não o espaço físico, que este quase todo mundo pode ver. Observe o espaço social, as relações, o que aconteceu entre as crianças e as professoras. As concepções que influenciaram a criação do jogo - uma obra de arte - também estiveram presentes no acontecimento da brincadeira. Toda a entonação inscrita no jogo - a colaboração, a interação, a ludicidade, a liberdade e a autoria também influenciaram o acontecer da prática, tecendo relações de outra natureza. E tudo isso recursivamente, uma vez que a natureza das relações sociais vivenciadas entre a professora e suas crianças também se materializa no material didático, no ambiente alfabetizador, no currículo, na avaliação. Ao escrutar as relações e as condições concretas nas quais se dá a prática alfabetizadora, as concepções que a habitam são reveladas.

E veja: aqui não se trata de observar qual teoria informa a prática, pois que a prática é o acontecer teórico na realidade, assim como a teoria é a prática registrada em linguagem conceitual. Porém, dizem por aí que "na prática, a teoria é outra" - uma fala recorrente nas escolas. Sua repetição reforça a ideia simplificadora de que a teoria seria um texto ineficaz à condução da prática. E como, realmente, teoria alguma se presta a ser aplicada a lugar algum, esta transposição do texto teórico ao fazer docente fracassa. A teoria, então, é substituída por um método. O método - este sim! - supostamente saberia dizer exatamente o que a professora deverá fazer na próxima segunda-feira. Em se tratando de alfabetização, parece-me que a refutação da teoria e a aderência aos métodos é bastante usual. Vejamos isso, desde as contribuições de Edgar Morin.

Para Morin (1999, p. 35) "uma teoria não é o conhecimento; ela permite o conhecimento". A teoria não é um texto instrucional a ser utilizado, mas um texto desde o qual há de se realizar um trabalho cognitivo que resultará em conhecimentos. O texto teórico nunca dirá como resolver as questões que a prática alfabetizadora coloca porque uma teoria não é um manual. A teoria é uma linguagem outra sobre a prática; é a prática em estado conceitual. Estas importantes reflexões de Morin (1999) contribuem para o entendimento do tratamento que, em grande parte, foi oferecido ao texto teórico decorrente de pesquisas acerca da alfabetização, na década de 1980, por Ferreiro \& Teberosky (1984).

Os resultados de seus estudos foram sintetizados por quem os leu, e grande parte do que se popularizou, refere-se ao que poderia ser diretamente aplicado ao ensino. Para Morin (1999), toda teoria pode sofrer degradação tecnicista, quando "conserva-se da teoria aquilo que é operacional, manipulador, aquilo que pode ser aplicado; a teoria deixa de ser logos e torna-se techné" (MORIN, 1999, p. 336 - grifos do autor). Junto a isso, pode também estar sujeita à pop-degradação, que é quando "eliminam-se as obscuridades, as dificuldades, reduz-se a teoria a uma ou duas fórmulas de choque; assim, a teoria vulgariza-se e difunde-se, à custa dessa simplificação de consumo" (MORIN, 1999, p. 336). 
Não é comum encontrar uma professora alfabetizadora que tenha lido os resultados comunicados por Ferreiro \& Teberosky (1984). Outros agentes realizaram este trabalho por ela: autores diversos, o mercado editorial, a administração escolar, as agências formadoras. À professora foi oferecida a síntese do texto teórico, diretamente voltada ao consumo planificado. É certo que, após isso, práticas conservadoras foram alteradas com a entrada de diferentes portadores de texto na sala de aula, com o incentivo às escritas das crianças e com expressiva transformação nas relações sociais que atravessam as práticas. Contudo, algumas destas práticas se limitaram ao "ativismo" que, segundo Paulo Freire (1987), trata-se de uma prática desprovida de reflexão, dada a ausência do estudo e do diálogo. Ao tomarem a síntese teórica e ao investirem nas conhecidas "didáticas dos níveis de conceitualização", muitas professoras abreviaram seu encontro com o texto teórico, com o estudo, com o diálogo e com a legitimação de conhecimentos tecidos em sua prática.

Os amplamente conhecidos "níveis de conceituação" renderam ao mercado editorial um grande público interessado no consumo de publicações de didáticas específicas de cada um destes níveis, e, na escola, ocuparam lugar de destaque na "avaliação diagnóstica" das crianças. A compreensão empobrecida de que uma determinada escrita revelava o nível da criança em sua evolução, foi alimentada pela entrada, na sala de aula, de orientações externas que mediavam as intervenções a serem realizadas em cada caso. Assim, uma "criança silábica" deveria cumprir atividades que a levassem a avançar para o nível seguinte. Atualmente, a facilidade de acesso a estas atividades se amplia de forma imensurável: estão presentes no livro didático, nas orientações institucionais e em qualquer buscador na Internet. É claro que isso não daria certo, uma vez que o texto teórico, que deveria provocar a investigação cotidiana de outros modos de apropriação que a criança faz da linguagem escrita, foi degradado em técnica.

A técnica e seus suportes - a fragmentação, homogeneização e hierarquização - adentram as relações sociais que se dão na sala de aula, configurando o espaço desde os seus pressupostos. $O$ ensino e a aprendizagem sucumbem a esta lógica, com a prevalência do repasse mecanicista e da expectativa pela absorção de conhecimentos parcelados. Naturaliza-se a ideia de que o ensinar e o aprender acontecem segundo a hierarquização de currículos prescritos, e a linguagem é reduzida às dinâmicas do objetivismo abstrato (BAKHTIN, 1992).

Daí a relevância de se pensar acerca da produção do espaço escolar, marcadamente atravessado pelas relações e práticas que ali se dão. Uma prática que se limita a replicar um produto inscreve, em si, as mesmas concepções que ele oferece. Ao assumir a prática enquanto "obra", a gênese de sua tecitura incorpora concepções que expandem o espaço e as relações com ideias autorais. Como aprendemos com Paulo Freire (1987), uma prática de liberdade, enfim.

\section{E cadê Ivan?}

Ivan Matviéitch adaptou-se prontamente ao bucho do crocodilo porque o espaço não se reduz à sua dimensão física e observável, mas também se constitui pelas relações sociais, concepções e dinâmicas presentes (LEFEBVRE, 2000). O bucho do bicho, fisicamente diferente da repartição pública onde trabalhava, não Ihe causou estranhamento porque the permitiu a continuidade do que praticava. Seu amigo, Siemión Siemiônitch, inconformado com o conformismo de Ivan, chegou a indagar, aflito: "Meu amigo, e a liberdade? [...] você está, por assim dizer, numa prisão, e o homem deve gozar a liberdade" (DOSTOIÉVSKI, 2011, p. 47).

Pobre Ivan. Deve estar lá, ainda hoje. 


\section{Referências}

ALVES, Nilda Guimarães. Formação de docentes e currículos para além da resistência. Revista Brasileira de Educação, v. 22, n. 71, p. 1-18, 2017. Disponível em https://www.scielo.br/pdf/rbedu/v22n71/1809-449Xrbedu-s1413-24782017227147. Acesso em: 18 fevereiro 2021.

BAKHTIN, Mikhail (Volochinov). Marxismo e filosofia da linguagem. São Paulo: Hucitec, 1992.

DOSTOIÉVSKI, Fiódor. O crocodilo e notas de inverno sobre impressões de verão. São Paulo: Editora 34, 2011.

FERREIRO, Emília; TEBEROSKY, Ana. Psicogênese da língua escrita. Porto Alegre: Artes Médicas, 1984.

FREIRE, Paulo. Pedagogia do Oprimido. Rio de Janeiro: Paz e Terra, 1987.

GARCIA, Regina Leite (org.). Alfabetização dos alunos das classes populares. São Paulo: Cortez, 1992.

GERALDI, João Wanderley (org.). O texto na sala de aula. São Paulo: Ática, 2011.

HELLER, Agnes. O cotidiano e a história. Rio de Janeiro: Paz e Terra, 1992.

LEFEBVRE, Henri. A vida cotidiana no mundo moderno. São Paulo: Ática, 1991.

LEFEBVRE, Henri. A produção do espaço. Trad. Doralice Barros Pereira e Sérgio Martins (do original: La production de l'espace. 4e éd. Paris: Éditions Anthropos, 2000).

MORIN, Edgar. Ciência com consciência. Rio de Janeiro: Bertrand Brasil, 1999.

MORTATTI, Maria do Rosário Longo. A "querela dos métodos" de alfabetização no Brasil: contribuições para metodizar o debate. Acolhendo a Alfabetização nos Países de Língua Portuguesa, v. 3, n. 5, p. 91-114, 2009. Disponível em: https://www.revistas.usp.br/reaa/article/view/11509. Acesso em: 6 maio 2021.

SAMPAIO, Carmen Sanches; LACERDA, Mitsi Pinheiro de; RIBEIRO, Tiago. Alfabetização sem cartilha: gestos, experiências e narrativas. Rio de Janeiro: Ayvu, 2019.

SANTOS, Boaventura de Sousa. Um discurso sobre as ciências. Porto: Edições Afrontamento, 2002.

SMOLKA, Ana Luiza Bustamante. A criança na fase inicial da escrita. A alfabetização como processo discursivo. São Paulo: Cortez, 1993.

Recebido em: 17/05/2021

Aceito em: 09/07/2021 